Article

\title{
High Performance Self-Compacting Concrete with Electric Arc Furnace Slag Aggregate and Cupola Slag Powder
}

\author{
Israel Sosa, Carlos Thomas* * Juan Antonio Polanco, Jesus Setién and Pablo Tamayo \\ LADICIM (Laboratory of Materials Science and Engineering Division), University of Cantabria, \\ 39005 Santander, Spain; sosai@unican.es (I.S.); polancoa@unican.es (J.A.P.); setienj@unican.es (J.S.); \\ pablo.tamayo@unican.es (P.T.) \\ * Correspondence: thomasc@unican.es
}

Received: 17 December 2019; Accepted: 19 January 2020; Published: 22 January 2020

check for updates

\begin{abstract}
The development of self-compacting concretes with electric arc furnace slags is a novelty in the field of materials and the production of high-performance concretes with these characteristics is a further achievement. To obtain these high-strength, low-permeability concretes, steel slag aggregates and cupola slag powder are used. To prove the effectiveness of these concretes, they are compared with control concretes that use diabase aggregates, fly ash, and limestone supplementary cementitious materials (SCMs, also called fillers) and intermediate mix proportions. The high density SCMs give the fresh concrete self-compacting thixotropy using high-density aggregates with no segregation. Moreover, the temporal evolution of the mechanical properties of mortars and concretes shows pozzolanic reactions for the cupola slag. The fulfillment of the demands in terms of stability, flowability, and mechanical properties required for this type of concrete, and the savings of natural resources derived from the valorization of waste, make these sustainable concretes a viable option for countless applications in civil engineering.
\end{abstract}

Keywords: self-compacting concrete; high-performance concrete; EAFS; cupola slag; electric arc furnace slag; mechanical properties

\section{Introduction}

The production of crude steel in Europe in the year 2017 was $168.3 \mathrm{Mt}$, almost $4 \%$ higher than in 2016, while the production by electric arc furnaces stands at $40.3 \%$ of total production $(67.8 \mathrm{Mt})$ [1] This steel production determines the amount of electric arc furnace slag (EAFS) generated during the fusion processes of scrap, totalling $18 \mathrm{Mt}$ for the year 2016 according to the Euroslag. In Europe, $12 \mathrm{Mt}$ of cast iron was generated in 2017. These values of production reveal the volume of slag resulting from the steel and cast iron industries that ends in landfills.

Several authors have incorporated different types of industrial waste as SCM's to concrete to modify its properties [2-4]. The pozzolanic properties of the slag generated in steel processes depend on the cooling process. With rapid cooling (as is the case of cupola slag) using water, the vitrification of the slag occurs, leaving the silica in an amorphous form and, therefore, susceptible to reaction. On the contrary, slow cooling (case of EAFS) promotes the complete crystallization of the phases and the inertization of the final product, thus not compromising its dimensional stability. The pozzolanicity of EAFS has been studied, but its reactivity has been reported to be rather weak [5] although it can be improved by remelting treatments [6]. The content of periclase $(\mathrm{MgO})$ in the slag causes a risk of potential expansion because the process of transformation into brucite $\left[\mathrm{Mg}(\mathrm{OH})_{2}\right]$ by hydration is slow or even delayed, putting the dimensional stability at risk. Given the possible expansive reactions, it is 
important to verify the efficiency of the stabilization treatments [5]. Another problem present in these aggregates is the significant deficit of particle sizes that pass through the smaller sieves in the sands. Therefore, the manufacture of mortars and concretes with EAFS sand entails mixing by combining them, either with natural sand or with inert filler $[7,8]$.

Another interesting practice in recovery/recycling strategies (in addition to incorporating EAFS aggregates) is to incorporate recycled aggregates from Construction and Demolition Wastes (C\&DW) to self-compacting concrete $[2,9,10]$. It has been demonstrated that their mechanical properties and durability [2,11-13] are suitable for structural concrete and they can be recycled several times [14].

SCMs are important for the self-compacting concrete (SCC), since they reduce the intergranular interaction [14], increase the cohesion and the flowability of the mixture, improve the hydration of the paste $[15,16]$, and strengthen the resistance to segregation. In hardened concrete, SCMs typically reduce capillarity and permeability but also mechanical properties can be reduced [14,17]. The cements most used for the manufacture of high strength SCC are Portland type I, however, blends containing one or more SCMs [18] and $350 \mathrm{~kg} / \mathrm{m}^{3}$ of CEM can be used readily [19]. It is recommended not to exceed $500 \mathrm{~kg} / \mathrm{m}^{3}$ (to avoid shrinkage problems) and to use SCMs to improve the workability of the fresh concrete. Several authors $[20,21]$ have established that drying shrinkage increases with drying speed and is proportional to the volume of cement paste, while the opposite occurs by increasing the lime filler content.

The use of cupola slag as a concrete SCM is not a common application despite of its sustainable benefits. Nevertheless, the use of granulated cupola furnace slag (GCFS) as fine and coarse aggregate $(0-16 \mathrm{~mm})$ in concrete does not seem a viable option [22]. However, some authors have demonstrated by the manufacture of mortars with various replacements [23] that is suitable to be used as SCM with the right activation process. Nevertheless, great reactivity has been reported when acting as substitution of ordinary Portland cement (OPC), showing 30\% compressive strength gains for 15\% replacements at 28 days [22].

The use of SCMs increases the concrete strength, and in greater proportion, by using SCMs with pozzolanic properties. According to Domone [23], the type and proportion of SCM has greater influence on the compressive strength than the water/filler ratio (cement + SCMs). Rozière et al. [20], reported the rise in compressive strength by increasing the limestone filler content, keeping the effective water/cement ratio and the amount of cement.

The use of SCC brings with it a series of advantages with respect to the conventional one such as better adhesion between the paste and the aggregates or the uniform distribution of the stresses during load applications [19], even having the same w/c ratio [24,25]. Some studies claim that indirect tensile strength is higher in SCC [25] due to its packed structure, other studies argue that there are no differences because this property does not depend on the paste content [23,24] and other studies argue that this greater paste content affects negatively [20]. Tensile splitting strength of SCC and conventional concrete with the same amount of cement and water/cement ratio is directly influenced by the type of aggregate used [19] and elastic modulus in SCC is lower because it has a lower proportion of coarse aggregate [21], and for the same compressive strength the SCC presents a bigger strain [19]. The stiffness of SCC can be $40 \%$ lower but in high strength concrete (the concrete considered in this study) the difference is reduced to $5 \%$.

The mechanical properties of concretes with EAFS are superior to those obtained with conventional aggregate concretes [26,27], mainly due to an improvement in the bond with the cement paste owing to the quality of the paste-aggregate interfacial transition zone (ITZ), which can be observed by means of a scanning microscope $[23,28]$. Experimentally, it has been found that the coarse fraction of EAFS contributes to the increase in compressive strength, tensile splitting strength, and elastic modulus. Similarly, the total substitution of fine aggregate leads to a reduction in compressive strength [29]. In terms of durability, concrete with EAFS is more vulnerable to frost and freeze-thaw cycles [30].

The use of EAFS in SCC is a challenge and very few studies have been done to date, mainly due to a decrease in flowability, also due to intergranular friction and a slight increase in density, 
although it has been possible to obtain stronger concretes than conventional ones [31], always using a significant amount of superplasticizer additive. Recently, Santamaría et al. [32,33] have demonstrated the feasibility of manufacturing SCC using EAFS as both coarse and fine, obtaining consistency classes of S4 and SF2 and reasonably good mechanical properties. Likewise, Qasrawi [34] advises not to use replacements greater than $50 \%$ of EAFS so as not to negatively affect the properties in the fresh state, mainly density, air content, and stability. With regard to these studies and broadly speaking, in this paper new concrete mixes are developed through the use of two different wastes, to obtain high-performance concrete. Analyzing in detail the specific differences with the works found in the literature, this paper presents these main novelties:

- The EAFS aggregate has not been separated by screening operations for mixing (only 2 fraction ranges have been used: 0/6 and 6/12).

- Two wastes from two different industrial processes are used in this research, both of the oxidation or reduction stages.

- The developed concrete mixes seek to obtain very high strength concrete without damaging the properties in the fresh state.

- A total replacement of the natural coarse and a partial replacement of the natural fines have been made.

- A comparison with a control concrete with high quality aggregates (diabase) has been made.

- It has been possible to value a new waste that would otherwise end up in landfills (cupola slag).

The aim of this study is to demonstrate that it is possible to obtain a high-performance concrete (HPC), considering this to have a strength between 70 and $150 \mathrm{MPa}$, which is self-compacting and also uses steel slag aggregate in all fractions (coarse, fine, and SCMs), obtaining a concrete with countless potential applications. For this purpose, the work consisted of two phases; in the first, mortar mixes were produced with different cement replacements for cupola slag, thus demonstrating the pozzolanicity of this material. In the second phase, self-compacting concretes have been compared with different types of coarse, fine, and locally available SCMs, demonstrating the improvement of mechanical performance with the use of EAFS aggregates and cupola slag (as SCM) with respect to conventional materials such as diabase (high quality aggregate) or siliceous sand.

\section{Materials and Methods}

\subsection{Materials}

Standardized siliceous sand, CEM I 52.5 R and cupola slag have been used for the manufacture of conventional mortars. For the manufacture of the different concrete proportions, coarse 6/12 (DC) diabase and coarse 6/12 (SC) slag have been used, limiting their quantities to avoid problems of blockage and segregation. Diabase sand 0/6 (DS), electric arc furnace slag 0/6 (SLS), and silica sand 0/2 (SIS) have been used as fine aggregates. The SCM used include limestone filler (LF), fly ash (FA), and cupola slag filler (CS). The granulometric distribution of the aggregates used (coarse and fine) according to EN 933-1 is shown in Figure 1. 


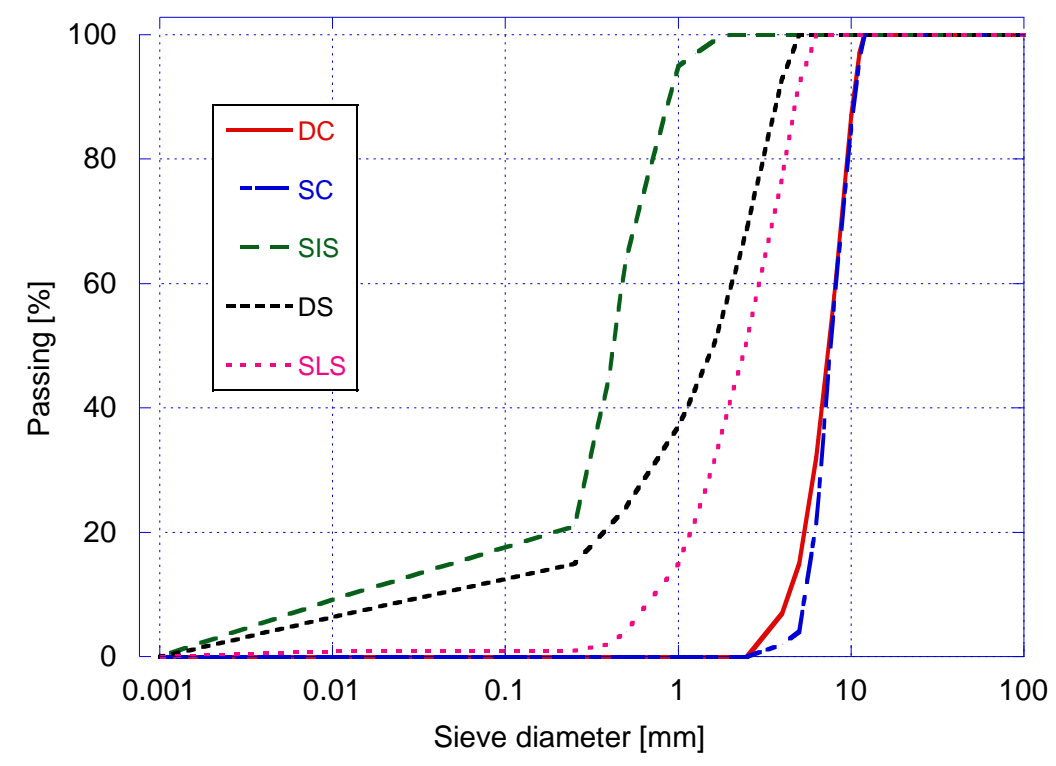

Figure 1. Aggregates granulometric grading.

The physical-mechanical properties of the aggregates have been determined by characterizing the bulk specific gravity and porosity according to EN 1097-3, the apparent specific gravity and water absorption according to EN 1097-6, the resistance to fragmentation determining Los Angeles coefficient according to EN 1097-2 and the aggregates crushing value according to UNE 83112. The fine aggregates (cement and SCM) have been characterized by determining the actual density according to UNE 80103 and by the specific Blaine surface according to EN 196-6. The results obtained are shown in Tables 1 and 2. Both types of aggregates have excellent mechanical properties and a $35 \%$ higher density in the case of EAFS.

Table 1. Main properties of the coarse aggregates used in the self-compacting concrete (SCC).

\begin{tabular}{ccccccc}
\hline Material & $\begin{array}{c}\text { Bulk } \\
\text { Specific } \\
\text { Gravity } \\
{\left[\mathbf{g} / \mathrm{cm}^{3} \text { ] }\right.}\end{array}$ & $\begin{array}{c}\text { Apparent } \\
\text { Specific } \\
\text { Gravity } \\
{\left[\mathbf{g} / \mathrm{cm}^{3} \text { ] }\right.}\end{array}$ & $\begin{array}{c}\text { Absorption } \\
{[\mathbf{v o l . \% ]}}\end{array}$ & $\begin{array}{c}\text { Open } \\
\text { Porosity } \\
{[\mathbf{w t} \%]}\end{array}$ & $\begin{array}{c}\text { Los Angeles } \\
{[\%]}\end{array}$ & $\begin{array}{c}\text { Aggregates } \\
\text { Crushing } \\
\text { Value }[\%]\end{array}$ \\
\hline EAFS coarse & 3.65 & 3.85 & 1.43 & 5.22 & 15 & 18 \\
Diabase coarse & 2.72 & 2.81 & 1.11 & 3.02 & 15 & 15 \\
\hline
\end{tabular}

Table 2. Main properties of the sands, supplementary cementitious materials (SCMs) and cement used in the SCC.

\begin{tabular}{ccc}
\hline Material & Actual Density $\left[\mathrm{g} / \mathrm{cm}^{3}\right]$ & Blaine Surface $\left[\mathrm{m}^{2} / \mathbf{k g}\right]$ \\
\hline EAFS sand & 3.77 & - \\
Diabase sand & 2.89 & - \\
Silica sand & 2.61 & - \\
Cupola slag SCM & 2.89 & 429.4 \\
Limestone filler & 2.65 & 274.1 \\
Fly ash SCM & 2.13 & 400.3 \\
CEM I 52.5 R & 3.11 & 495.7 \\
\hline
\end{tabular}

The chemical characterization of the slags used was carried out by means of X-ray fluorescence (XRF), in order to determine the semi-quantitative concentration of compounds in oxides represented by percentages (Table 3). For this characterization an ARL-ADVANT-XP Thermo-spectrometer was used. It was observed that the main components of slags were iron, calcium, and silicon oxides, although there were traces of chromium and titanium oxides, probably generated during the injection of oxygen. 
On the other hand, the cupola slag shows high concentrations of silicon, calcium, and aluminum oxides, the first being an indicator of the possible reactivity of the material, since it is in an amorphous state. The compositions of the rest of the materials were obtained by Energy-dispersive X-ray spectroscopy (EDX) using a Zeiss EVO MA15 scanning electron microscope (SEM) equipped with an Oxford Instruments $\mathrm{X}$-ray detector, selecting different representative areas of particles chosen randomly.

Table 3. Chemical composition of the materials used.

\begin{tabular}{ccccccccccccc}
\hline Compound [wt.\%] & $\mathrm{Fe}_{2} \mathrm{O}_{3}$ & $\mathrm{CaO}$ & $\mathrm{SiO}_{2}$ & $\mathrm{Al}_{2} \mathbf{O}_{3}$ & $\mathbf{M g O}$ & $\mathbf{M n O}$ & $\mathrm{Cr}_{2} \mathbf{O}_{3}$ & $\mathrm{TiO}_{2}$ & $\mathbf{N a}_{2} \mathbf{O}$ & $\mathbf{S O}_{3}$ & $\mathrm{~K}_{2} \mathbf{O}$ & Others \\
\hline EAFS & 37.90 & 30.26 & 12.00 & 7.4 & 4.93 & 4.53 & 1.15 & 0.53 & - & - & - & $<0.5$ \\
Cupola slag & 6.34 & 29.97 & 43.56 & 13.64 & 2.1 & 2.80 & - & 0.51 & - & - & - & $<0.5$ \\
Fly ash & 7 & 6.1 & 55 & 20.4 & 2.6 & - & - & 0.9 & 1.2 & 4 & 2 & - \\
CEM I 52.5 R & 3.38 & 66.6 & 17.81 & 4.79 & 1.3 & - & - & 0.2 & - & 4.49 & 0.78 & - \\
\hline
\end{tabular}

The expansiveness of the EAFS is one of its main problems, and can cause cracking of concrete in the medium/long term. To avoid this phenomenon, EAFS aggregates have been submerged in pools for $24 \mathrm{~h}$ and have remained wet in storage stacks for 3 months, in order to hydrate free lime and magnesia. The expansiveness of the aggregates was determined according to EN 1744-1, obtaining values of $0.16 \mathrm{vol} . \%$ at $24 \mathrm{~h}$ and $0.17 \%$ vol. at $168 \mathrm{~h}$, the first value being those required when the $\mathrm{MgO}$ content is less than $5 \%$.

The mortar proportions (Table 4) were carried out with CEM I 52.5 R, CEN standardized sand and in accordance with the amounts proposed by EN 196-1 (except the amount of sand, slightly higher). The mortars were cured submerged in water at a temperature of $20 \pm 1^{\circ} \mathrm{C}$. The manufacture of these mortars (M) was carried out using replacements of $0,10,20,30 \mathrm{vol} . \%$ of cement by cupola slag filler, in order to establish the pozzolanity of the cupola slag compared to cement.

Table 4. Mix proportions of the mortars [g].

\begin{tabular}{ccccc}
\hline Material [g] & $\mathbf{M - 0} \%$ & $\mathbf{M - 1 0} \%$ & $\mathbf{M - 2 0} \%$ & $\mathbf{M - 3 0 \%}$ \\
\hline CEM I 52.5 R & 450 & 405 & 360 & 315 \\
Silica sand & 1450 & 1450 & 1450 & 1450 \\
Cupola slag filler & - & 42 & 84 & 126 \\
Water & 225 & 225 & 225 & 225 \\
w/c ratio & 0.5 & 0.6 & 0.7 & 0.8 \\
\hline
\end{tabular}

For the mix proportions of the self-compacting control concrete, the methodology proposed by Dinakar et al. [35] was used, based on compressive strength. The design goal was to obtain a high-performance concrete with $100 \mathrm{MPa}$ strength at 90 days, for which an amount of cement of $450 \mathrm{~kg} / \mathrm{m}^{3}$, and the use of $2 \%$ (of the cement weight) of a superplasticizer additive (enabling a more viscous paste to be obtained) was selected. A limestone filler quantity of $100 \mathrm{~kg} / \mathrm{m}^{3}$ was used, thus using a total amount of cement, SCMs, and filler of $550 \mathrm{~kg} / \mathrm{m}^{3}$, less than the maximum $600 \mathrm{~kg} / \mathrm{m}^{3}$ recommended by EHE-08 [36] and EFNARC [37]. An attempt was made to maximize the coarse content (50 vol.\%) to obtain greater use of the by-product without affecting segregation or blocking. Likewise, the amount of water used was optimized so as not to adversely affect the strength without affecting the flowability or segregation.

Four concrete mixes were made: three control mixes that use diabase coarse with three different filler materials (limestone, fly ash and cupola slag) and a fourth that uses EAFS coarse with cupola slag filler. The first three dosages enable the comparison of the SCM used, while the fourth enables the comparison of high strength natural aggregates with siderurgical aggregates. The three control dosages are analogous, while the fourth had to be modified because it presented notable deficiencies in the fresh state. The sand content was increased because SLS has less fine aggregates than DS and the latter has a much more cavernous and angular geometry. In addition, the reduction of SC enabled 
slump to be improved and prevented concrete blockage. A slightly lower w/c ratio was used in this case due to the limitation due to the segregation of the EAFS aggregate.

The preparation of these self-compacting concretes was similar to that of conventional concretes, with the exception of kneading time (12 min), considerably increased to ensure the complete distribution of the superplasticizer additive. The mixtures were made in a $120 \mathrm{~L}$ rotating drum mixer, with $30 \mathrm{~L}$ batches. The samples were been demolded at $24 \mathrm{~h}$ and were cured in a moisture chamber, at a constant temperature of $20 \pm 2{ }^{\circ} \mathrm{C}$ and constant humidity of $95 \pm 5 \%$. The final proportions, in $\mathrm{kg} / \mathrm{m}^{3}$, of the mixtures appear in Table 5.

Table 5. Concrete mix proportions $\left(\mathrm{kg} / \mathrm{m}^{3}\right)$.

\begin{tabular}{ccccc}
\hline Concrete & SCC-DC-LF & SCC-DC-FA & SCC-DC-CS & SCC-SC-CS \\
\hline Diabase coarse (DC) & 896 & 896 & 896 & - \\
Slag coarse (SC) & - & - & - & 1101 \\
Diabase sand (DS) & 411 & 411 & 411 & - \\
Silica sand (SIS) & 386 & 386 & 386 & 605 \\
Slag sand (SLS) & - & - & - & 444 \\
Limestone filler (LF) & 100 & - & - & - \\
Fly ash (FA) & - & 80 & - & - \\
> Cupola slag filler (CS) & - & - & 109 & 109 \\
CEM I 52.5 R & 450 & 450 & 450 & 450 \\
Water & 180 & 180 & 180 & 174 \\
Superplasticizer additive & 9 & 9 & 9 & 9 \\
w/c ratio & 0.40 & 0.40 & 0.40 & 0.39 \\
\hline
\end{tabular}

\subsection{Properties of Fresh Concrete}

The self-compactability of a concrete depends essentially on its filling ability, its passing ability, and its static and dynamic stability or segregation resistance. The characterization of the properties in the fresh state of self-compacting concrete is different from conventional concretes, using in this study the slump flow, the L-box and the V-funnel tests. The slump flow test has been carried out according to EN 12350-8, to obtain the flow capacity of the concrete, as well as its stability. To carry out this test, the Abrams cone (EN 12350-2) and a $900 \times 900 \mathrm{~mm}$ metal steel plate have been used, on which three concentric circles are marked, measuring the conjugated diameters of the drained concrete and determining the average diameter (SF). This test also determines the time it takes for the concrete to cover the $500 \mathrm{~mm}$ circle $\left(\mathrm{t}_{500}\right)$, which allows the relative viscosity of the concrete to be evaluated, as well as the flow rate. According to EN 206-9 the permissible range for this test is between 550 and $850 \mathrm{~mm}$ for the SF and the $t_{500}$ must be less than or equal to $8 \mathrm{~s}$.

The L-box test was carried out according to EN 12350-10 using 3 bars. It measures the ability to pass through the reinforcements, as well as stability. The concrete was poured through the upper opening, measuring the height of the concrete in the vertical section (H1) as well as the height at the end of the horizontal section (H2). The "passing ability" of concrete for the PL test is defined as the $\mathrm{H} 2 / \mathrm{H} 1$ ratio. According to EN 206-9, there are two kinds of passing capacity delimited by a PL of 0.8 . The V-funnel test has been carried out according to EN 12350-9 to assess the viscosity, the capacity to pass through confined spaces and the mold filling capacity. The test measures the time it takes for the concrete to flow through the V-mold, from the opening of the lower gate until the mold is emptied. According to EN 206-9, the permissible $t_{\mathrm{v}}$ range is $0-25 \mathrm{~s}$, with $9 \mathrm{~s}$ being the limit between the two existing categories.

\subsection{Physical Properties of the Concrete Mixes}

The apparent, bulk and saturated-surface-dry (SSD) specific gravities were determined following EN 12390-7 and, additionally, both accessible porosity (vol.\%) and water absorption (wt.\% ) were obtained according to UNE 83980 applying air vacuum. The physical properties were determined 
on nine thirds of standard cylindrical specimens of $150 \times 300 \mathrm{~mm}$ at 28 days per mix (a total of 36 specimens), specimens in which the upper and lower ends were cut in order to avoid edge effects.

\subsection{Mechanical Properties of the Mortars}

The mortars underwent the mechanical tests proposed by and according to EN 196-1. These tests consisted first of all in the determination of flexural strength and then in the determination of compressive strength on each of the halves obtained in the first test. Three specimens were manufactured per age and per mix (64 specimens in total), with tests being performed at 7, 28, 60, and 90 days. The tests were carried out on a servohydraulic machine with a capacity of $250 \mathrm{kN}$ at rates of $0.05 \mathrm{~mm} / \mathrm{s}$ for flexural tests and $0.1 \mathrm{~mm} / \mathrm{s}$ for compression tests.

\subsection{Mechanical Properties of the Concrete}

The uniaxial compressive strength was determined according to EN 12390-3 on four cubic specimens of $100 \mathrm{~mm}$ at 7, 28, 90, 180 and 365 days per mix (a total of 80 specimens). The use of these specimens is compatible with the maximum aggregate size and correction coefficients were applied if necessary. This test was carried out on a servohydraulic machine with a capacity of $1500 \mathrm{kN}$ at a rate of $0.5 \mathrm{MPa} / \mathrm{s}$, after removing the specimens from the moisture chamber and waiting for their surface drying.

The compressive elastic modulus was determined following EN 12390-13 on 1 standardized cylindrical specimen at 7, 28, 90, 180, and 365 days of age per mix (a total of 20 specimens). Method A was applied, which includes 3 preload cycles to check the correct positioning of the specimens and subsequently 3 loading/unloading cycles were applied. The initial and final stress and strain values enable the initial elastic modulus (first cycle) and the stabilized elastic modulus (third cycle) to be obtained. The specimens were capped with sulfur on their upper face and fitted with strain gauges $120 \mathrm{~mm}$ in length. The test was carried out on a servohydraulic machine with a capacity of $2000 \mathrm{kN}$ at a load/unload rate of $0.7 \mathrm{MPa} / \mathrm{s}$.

The splitting tensile strength test was carried out according to EN 12390-6, on 9 thirds of standard cylindrical specimens of $150 \times 300 \mathrm{~mm}$ at 90 days per mix (a total of 36 specimens). A servohydraulic testing machine of $1500 \mathrm{kN}$ capacity and a load rate of $0.05 \mathrm{MPa} / \mathrm{s}$ was used for this purpose.

\section{Results and Discussion}

\subsection{Properties of Fresh Concrete}

The properties in the fresh state of the different mixes of SCC appear in Table 6. The mixes that incorporate diabase coarse and limestone filler or slag filler have an average slump flow of 750-850 mm corresponding to the upper category or SF3 according to EN 206-9, equivalent to category AC-E3 according to EFNARC. In the case of using slag coarse or diabase aggregates with fly ash, the average slump flow is reduced to $650-750 \mathrm{~mm}$, corresponding to category SF2 according to EN 206-9 or AC-E2 according to EFNARC, ideal workability for conventional applications as pillars and walls. The use of slags as coarse aggregate penalizes slump flow by $10 \%$, which is compatible with the results obtained in conventional concretes, where the use of slags leads to a general decrease in workability $[29,30]$. The decrease in the flowability of concrete with slags is due to their increased friction, as well as their angular geometry and their high density. The $t_{500}$ for the SCC-DC-FA and SCC-DC-CS mixes are classified as VS2 according to EN 206-9 and AC-V1 according to the EFNARC, with values at the limit of the recommendations. On the other hand, the mixes with limestone filler and slag coarse fall outside the categories proposed by the recommendations, the latter due to the viscosity of the paste itself, since a greater amount of fines is used. The slump test of the SCC-SC-CS mix can be seen in the following link: https://www.youtube.com/watch?v=rZUtHjiP4dw. 
Table 6. Rheological properties of the self-compacting concrete in fresh state.

\begin{tabular}{cccccc}
\hline \multirow{2}{*}{ Concrete } & \multirow{2}{*}{ V Funnel Test [s] } & L-Box Test [\%] & \multicolumn{3}{c}{ Slump Flow Test } \\
\cline { 4 - 6 } & & & $\mathbf{D}_{\mathbf{1}}$ [mm] & $\mathbf{D}_{\mathbf{2}}$ [mm] & $\mathbf{t}_{\mathbf{5 0 0}}$ [s] \\
\hline SCC-DC-LF & 80 & 0.89 & 740 & 770 & 9 \\
SCC-DC-FA & 46 & 0.84 & 740 & 730 & 7 \\
SCC-DC-CS & 89 & 0.91 & 760 & 780 & 8 \\
SCC-SC-CS & 136 & 0.80 & 690 & 680 & 10 \\
\hline
\end{tabular}

The flowability is at odds with viscosity, incorporating high-density aggregates requires a viscous paste (high fine content and low w/c ratio) that prevents the segregation of aggregates. Increasing viscosity also means obtaining a higher volume of occluded air or a poorer surface finish, which is why it is important to establish a compromise between both variables. In Figure 2, the correct distribution of aggregates in all mixes can be observed. In the case of SCC-DC-LF, areas with higher aggregate concentration and a mortar band of about $10 \mathrm{~mm}$ thick and slight bleeding are observed on the perimeter of the disk. The behavior of the SCC-DC-FA is more stable, favored by the shape of the fly ash particles that provide greater homogeneity in slump. Although it also has a mortar band about $10 \mathrm{~mm}$ thick, no bleeding is reported. In the case of SCC-DC-CS there is a homogeneous distribution of aggregates but a decrease in the viscosity of the paste and consequently greater bleeding and exudation due to incorporating the vitreous powder. The disk of the SCC-SC-CS shows a very homogeneous, symmetrical, and stable distribution. There is no segregation or concentration of coarse aggregates despite the high density of slags although there is a mortar band of about $10 \mathrm{~mm}$ around the disk.
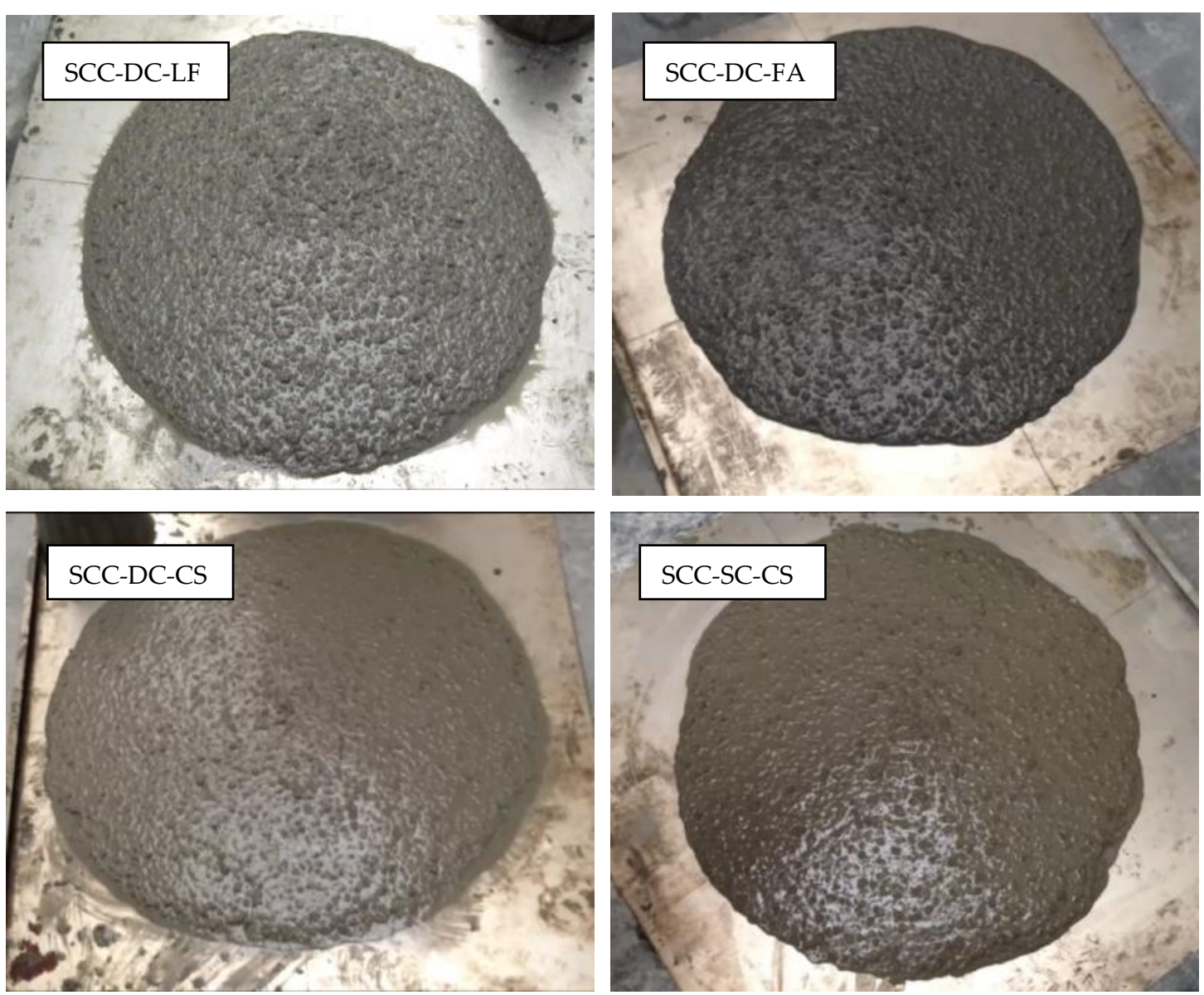

Figure 2. Slump disks detail of all mixes. 
The values obtained from PL are consistent with the slump measured. The results of the L-box test (Table 6) show a passing capacity (PL) greater than 0.8 in all cases, which allows the mixes to be classified as PL1 according to EN 206-9 and as AC-RB2 according to EFNARC. In none of the cases has there been blockage in the bars and it should be noted that the SCC-SC-CS mix has shown a flow rate through confined spaces well below the other mixes, taking twice as long to stabilize the final height $\mathrm{H} 2$. This low-passing speed is associated with the high friction in the sliding between layers of paste with slag sand and cupola filler.

The results for the V funnel test also appear in Table 6. As was already apparent in the L-box test, the greater times correspond to the mixes that use cupola slag filler and slag sand. The difference between using limestone filler and cupola slag filler is almost negligible, although the use of fly ash improves the mobility of the mixture due to its spherical shape. On the other hand, the values obtained with the SCC-SC-CS are 70\% higher than with SCC-DC-LF and SCC-DC-SC, a value that rises to $300 \%$ higher in comparison with SCC-SC-FA. The SCC-SC-CS is the most affected in this parameter due to the high viscosity of the paste, this viscosity also generates thixotropy gelation, observed after keeping the fresh mixture at rest. In all mixes the values are higher than the $25 \mathrm{~s}$ established by EN 206-9 for conventional SCC due to the high coarse content, which makes it difficult to pass through the funnel. Therefore, the designed mixtures are not recommended for highly confined areas, obliging modification of the mixture.

\subsection{Physical Properties of the Concrete Mixes}

The physical properties of the concrete mixes are shown in Table 7. The high density of EAFS gives the concrete with slags and the mixture of cupola slag around $15 \%$ more density than the reference concrete with diabase aggregates, except the mix that contains fly ash, where the ratio goes up to $20 \%$. This is partly due to the low actual density of the fly ash $\left(2.13 \mathrm{~g} / \mathrm{cm}^{3}\right)$.

Table 7. Physical properties of the concrete mixes.

\begin{tabular}{cccccc}
\hline Concrete & $\begin{array}{c}\text { Apparent } \\
\text { Specific } \\
\text { Gravity } \\
{\left[\mathrm{g} / \mathbf{c m}^{\mathbf{3}}\right]}\end{array}$ & $\begin{array}{c}\text { Bulk Specific } \\
\text { Gravity } \\
{\left[\mathrm{g} / \mathrm{cm}^{3}\right]}\end{array}$ & $\begin{array}{c}\text { Bulk SSD } \\
\text { Specific } \\
\text { Gravity } \\
{\left[\mathrm{g} / \mathbf{c m}^{\mathbf{3}}\right]}\end{array}$ & $\begin{array}{c}\text { Open Porosity } \\
{[\mathbf{v o l .} \%]}\end{array}$ & $\begin{array}{c}\text { Water } \\
\text { Absorption } \\
{[\mathbf{w t} . \%]}\end{array}$ \\
\hline SCC-DC-LF & 2.47 & 2.63 & 2.53 & 5.98 & 2.41 \\
SCC-DC-FA & 2.29 & 2.58 & 2.4 & 11.59 & 5.08 \\
SCC-DC-CS & 2.48 & 2.66 & 2.55 & 6.9 & 2.78 \\
SCC-SC-CS & 2.88 & 3.03 & 2.93 & 5.21 & 1.82 \\
\hline
\end{tabular}

Due to the difference in densities between the mixes, it is ideal to perform a comparison between the open porosity (vol.\%) and not the water absorption (wt.\%). The mix with the lowest open porosity is the one that uses EAFS and cupola slag due, in part, to having a slightly lower w/c ratio and due to the higher density of aggregate particles, which facilitate the expulsion of trapped air (greater self-compaction). Conversely, the mix with greater open porosity is the one that uses diabase coarse and fly ash (220\% greater than the previous one), this is due to a reaction between the plasticizer additive and the fly ash, which generates bubbles of around $1 \mathrm{~mm}$.

In the comparison between SCC-DC-LF and SCC-DC-CS, it can be concluded that there are no significant differences in any of the properties shown between the limestone filler and the cupola slag SCM, it being necessary to analyze the mechanical properties of both mixes to establish the benefits of each filler. The visual aspect of each mix in the hardened state is shown in Figure 3, where a better orientation of the aggregates in the filling can be seen in the SCC-SC-CS mix. 

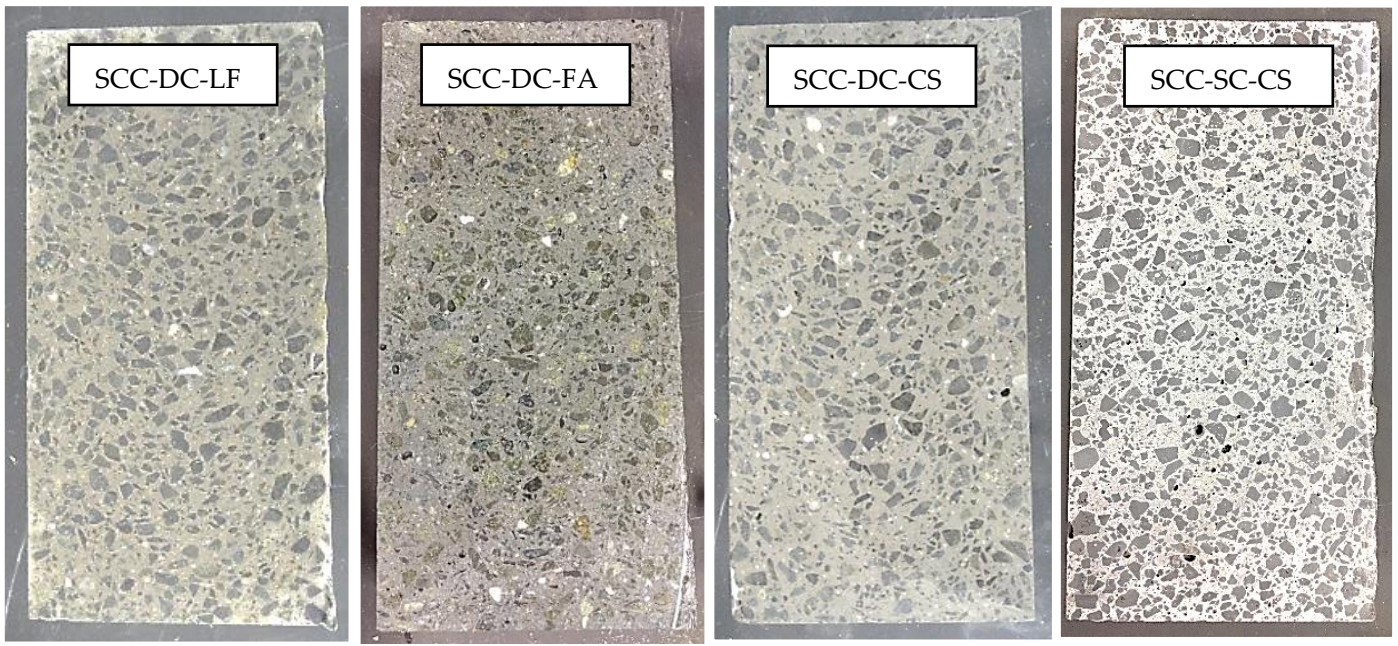

Figure 3. Appearance of the concrete mixes.

\subsection{Mechanical Properties of the Mortars}

Figure 4 shows the results of the mechanical properties of mortars that incorporate several replacements of Portland cement. Compressive strength increases with the age for all replacements following a logarithmic trend $\left(\mathrm{R}^{2} \approx 0.85\right)$, while intermediate replacements shows intermediate behavior between maximum replacement and reference mortars. After 7 days, mortars with a $30 \%$ replacement show a $27 \%$ loss in compressive strength with respect to the reference mortar, showing a slow rate of hydration reactions. This loss is reduced to $12 \%$ at 28 days and $5 \%$ at 60 days. At 90 days, the strength shown for all replacements tends to converge because the start of hydration of the alite and the peak of hydration occur much later when using cupola slag SCM than when using Portland cement (the speed of the reactions is slower when using cupola slag) [38].
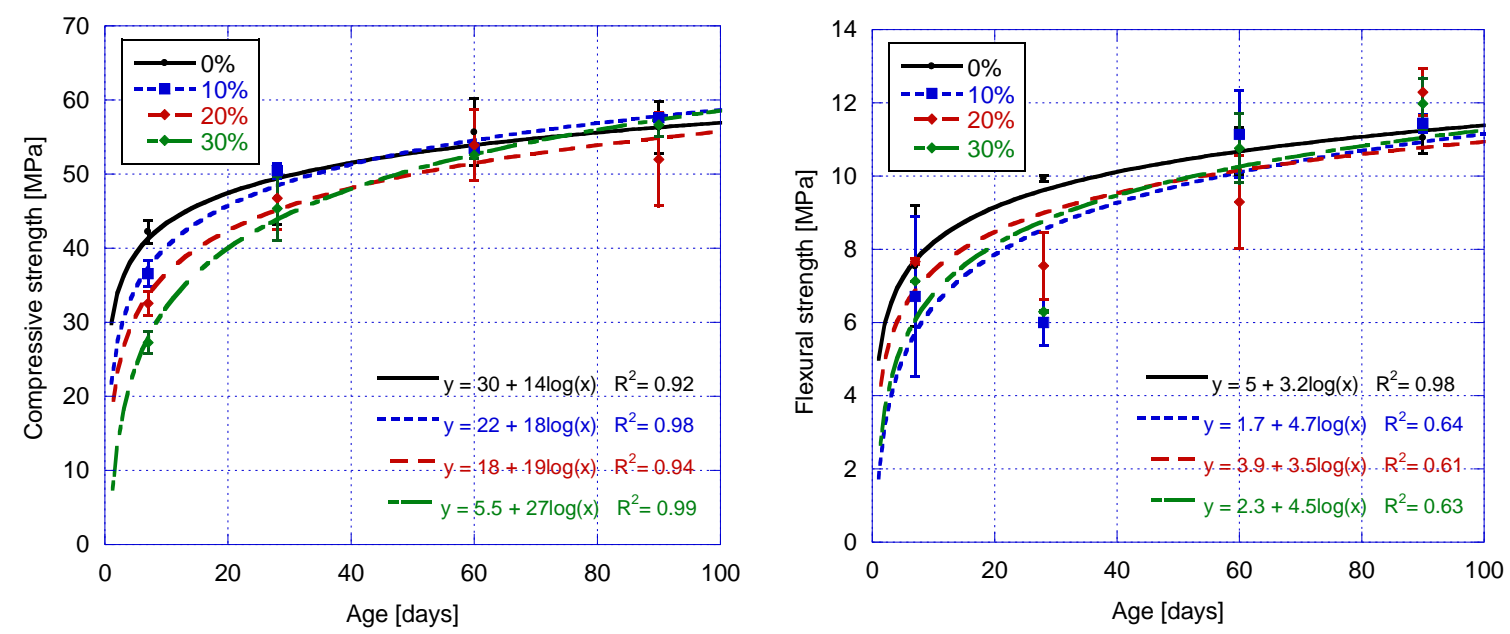

Figure 4. Mechanical properties of mortars with several cement replacements with cupola slag.

Flexural strength (Figure 4) also increases with age for all replacements and analogously to compressive strength. After 7 days, the strength shown by $30 \%$ replacements is $25 \%$ lower than that obtained with the reference mortars. For 28 and 60 days the losses reach $10 \%$ and $6 \%$ respectively. Again, there is a development of strength with age, more pronounced when cupola slag SCM is incorporated into the mortar. For ages over 90 days the values tend to converge again, showing the slowness of the reactions and demonstrating the strong pozzolanic character of the cupola slag. 


\subsection{Mechanical Properties of the Concrete Mixes}

The evolution of the compressive strength over time for the different mixes is shown in Figure 5. Regarding the SCM's, comparing the 3 mixes that use natural aggregates (identical proportions), it is observed that the cupola slag (SCC-SC-CS and SCC-DC-CS mixes) provides more strength than the limestone filler and the fly ash (SCC-DC-LF and -SCC-DC-FA), both at short and long ages, despite the instability of the mix. This demonstrates the pozzolanic character of the cupola slag, showing a $13 \%$ greater compressive strength at 28 days and $11 \%$ greater at 360 days than both mixes and showing once again the importance of the promotion of the pozzolanic reaction by the SCM's in high-performance self-compacting concrete [39]. Of these last two (SCC-DC-LF and -SCC-DC-FA), it is surprising that with the fly ash similar strength is achieved as with the limestone filler, despite the greater porosity of the first, due to the high alkalinity of concrete, which favors the reaction of the SCM. In the comparison of the SCC-SC-CS with the rest of the mixes, great improvements in compressive strength are observed at all ages due mainly to three factors: better compressive strength of EAFS, higher coefficient of friction between particles due to the EAFS roughness, and a better bond between paste and aggregates. Comparing SCC-SC-CS with SCC-DC-CS, there is an increase in resistance of $5 \%$ at 28 days and $13 \%$ at 360 days due to the incorporation of the EAFS aggregate and a slight reduction in the w/c ratio. Comparing SCC-SC-CS with SCC-DC-LF and SCC-DC-FA, the increase is $20 \%$ at 28 days and $25 \%$ at 360 days. Figure 6 (obtained by scanning electron microscopy) shows the appearance of the cupola slag particles at $5000 \times$ after reacting, generating compounds in the form of parallel hexagonal plates, perfectly integrated in the paste and in combination with the cement hydration products. The composition of these plates, determined by EDX, corresponds to hydrated calcium aluminosilicates.
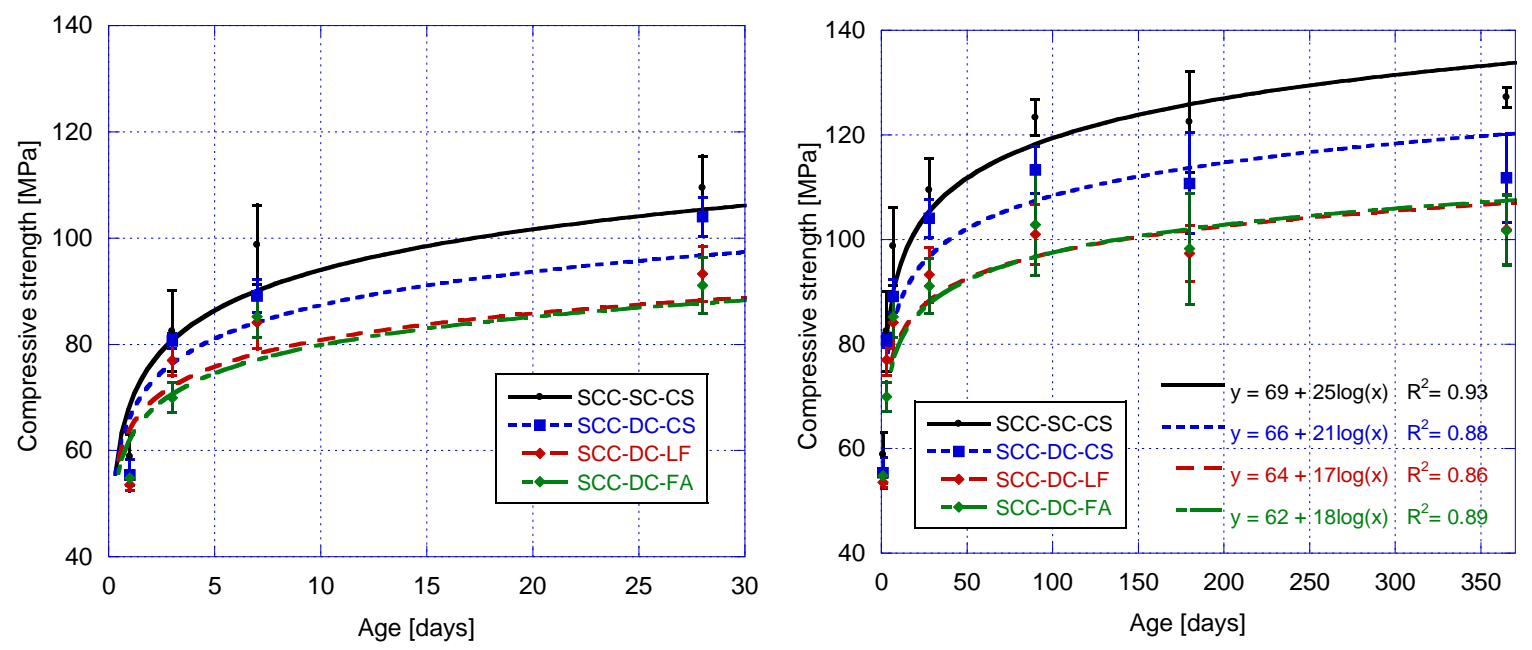

Figure 5. Evolution of the compressive strength for the different mixes: the first at 28 days (left) and the second at 360 days (right). 


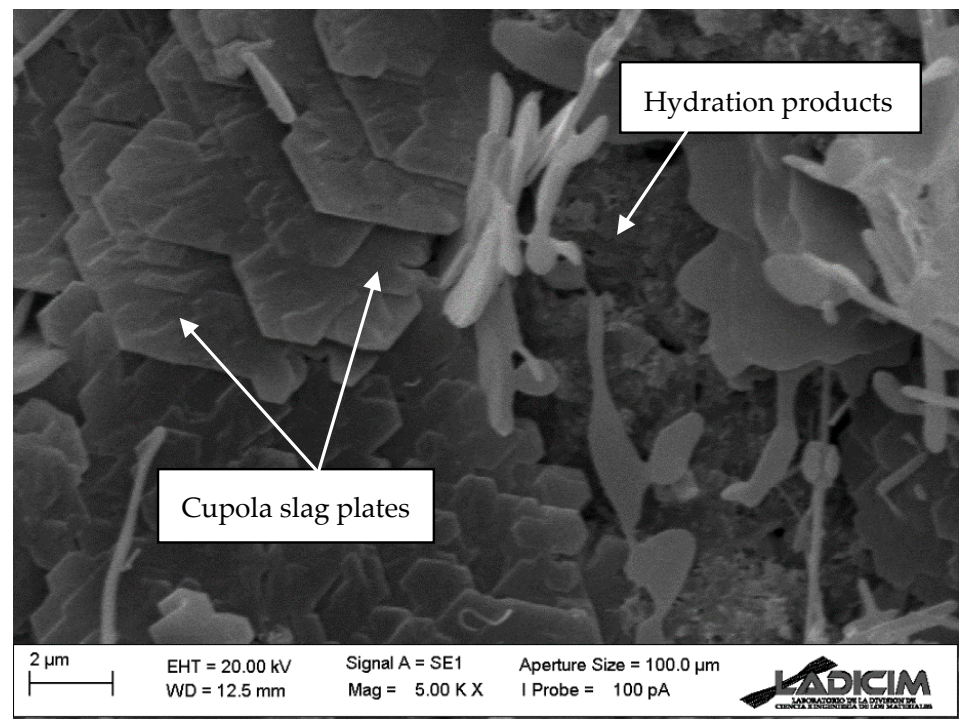

Figure 6. Appearance of the cupola slag after reacting on the cement paste (5000 $\times)$.

In absolute terms, the mixes that incorporate cupola slag exceed $100 \mathrm{MPa}$ at 28 days while the rest of the mixes are over $90 \mathrm{MPa}$, all of which can be considered high-performance concretes. From 28 to 360 days, the most evolved mix is SCC-SC-CS (16.5\%) followed by SCC-DC-FA (12\%) and SCC-DC-LF $(7.5 \%)$ and SCC-DC-CS (7.5\%). Also, at 360 days, the mix with cupola SCM and EAFS reaches 130 MPa. Comparing Figures 4 and 5, a remarkable increase in strength can be observed when cupola slag is used as a filler, rather than a cement substitute, which indicates cupola slag's potential as a reactive filler.

In Figure 7, the appearance of some of the cracking of the cubic specimens tested at 365 days is presented. As can be seen, due to the high stress applied to these concretes and the excellent paste-aggregate interface, the crack planes have propagated through the paste and aggregates, releasing all their energy through explosive cracks.
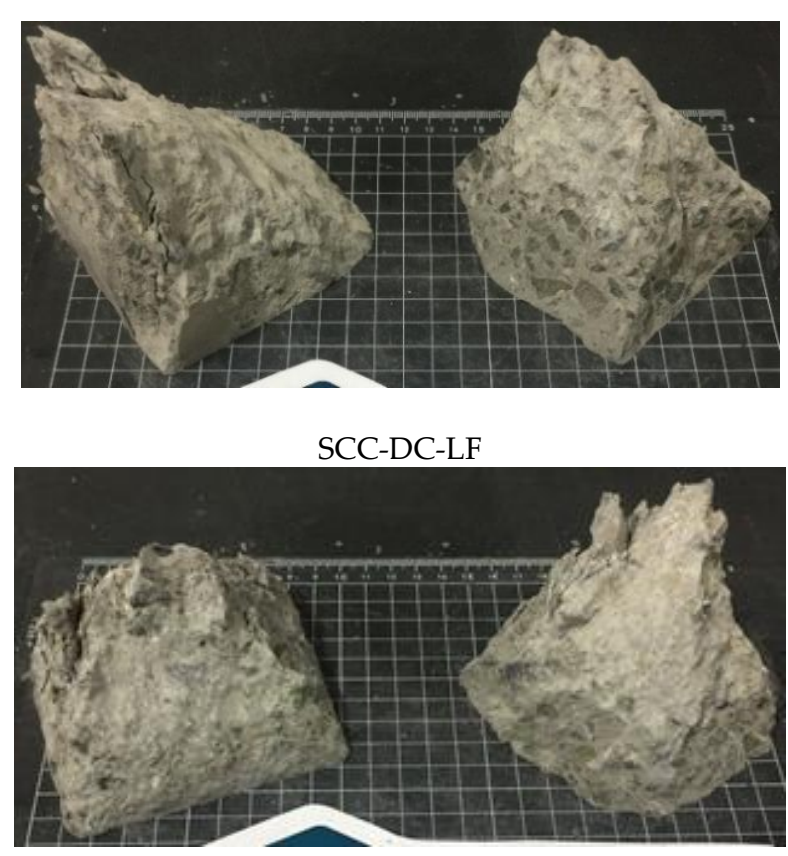

SCC-DC-CS
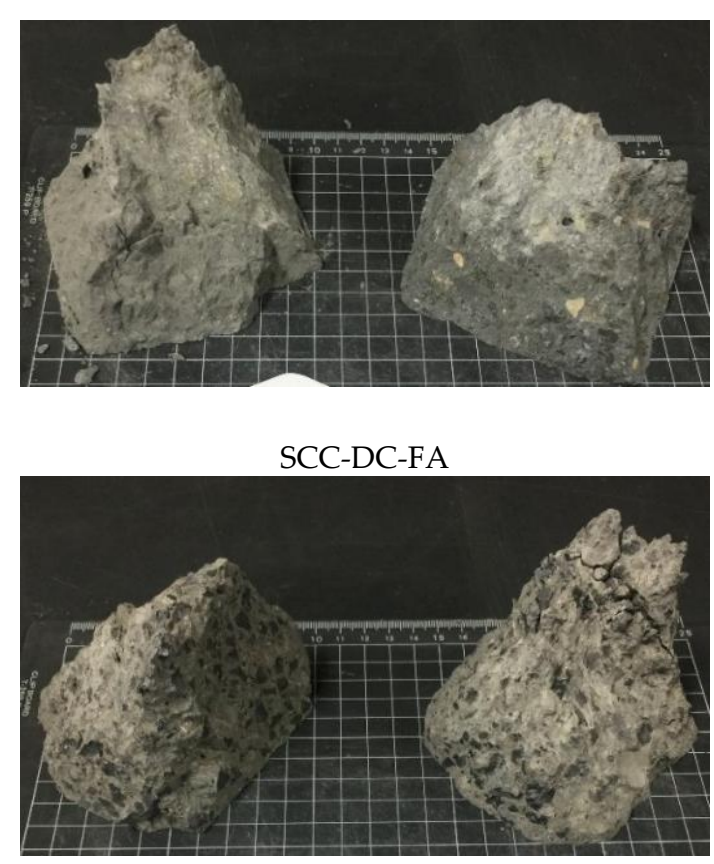

SCC-SC-CS

Figure 7. Detail of the compressive strength cracking (365 days). 
The analysis of the cracking behavior of these materials is important, and in addition to the visual analysis, there are methodologies to determine the cracking load from deflection-load curves in flexural tests [40].

The evolution of the elastic modulus over time is shown in Figure 8. Among the mixes that use diabase aggregate, it is observed that SCC-DC-FA has the smallest elastic modulus (37 and 40 GPa at 28 and 360 days), which is due to the great porosity of the mix, allowing greater deformations. The SCC-DC-CS mix shows a modulus 10\% higher than SCC-DC-LF, having a slightly lower porosity, due to the pozzolanic character and the greater Blaine surface of the cupola slag SCM. On the other hand, the SCC-SC-CS mix shows an elastic modulus far superior to the rest of the mixes (56 and 59 GPa at 28 and 360 days), being $24 \%$ and $18 \%$ higher than for SCC-DC-CS at 28 and 360 days respectively. This is due to the high EAFS modulus (and its iron nature), a slightly lower w/c ratio and a $25 \%$ lower porosity (Table 1). Compared with compressive strength, the elastic modulus has increased less with age, obtaining at 7 days approximately $90 \%$ of the final elastic modulus in all mixes.
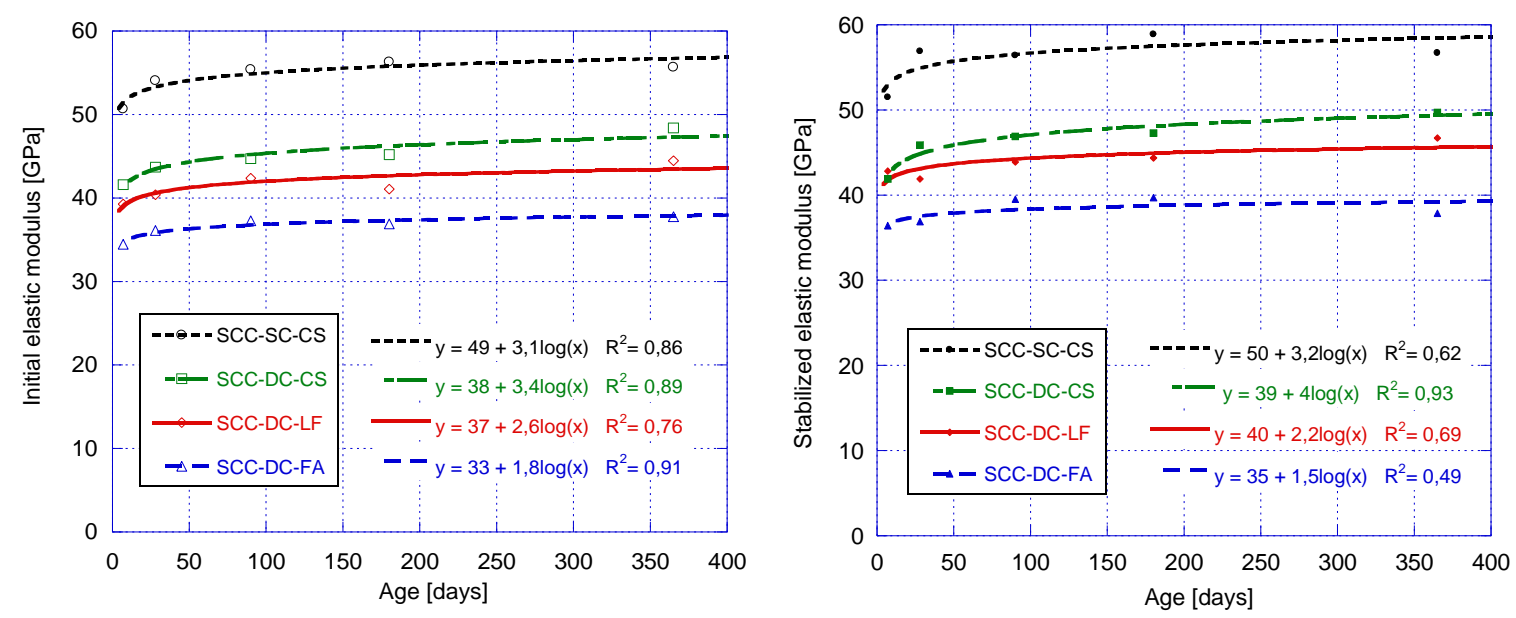

Figure 8. Evolution of the initial elastic modulus (left) and the stabilized elastic modulus (right) for the different concrete mixes.

On the other hand, the stabilized elastic modulus is slightly higher in all cases, since the material undergoes small permanent deformations for loads below the elastic limit in all cycles

The results of tensile splitting (Brazilian) strength for all mixes at 90 days are presented in Figure 9. Among all the mixes that use natural aggregate, it is observed that SCC-DC-FA has the lowest tensile splitting strength $(4.5 \mathrm{MPa})$, due to a high porosity and a lower bonding in the interface transition zone favored by the smooth surface of the fly ash particles. The SCC-DC-LF mix is the next one with the highest tensile splitting strength (5.4 MPa), slightly lower than SCC-DC-CS (5.7 MPa), where once again the reactive character of the cupola slag SCM shows an improvement of the mechanical properties. For this property, there are no differences between using natural aggregate or siderurgical aggregate, as shown by the comparison between SCC-DC-CS and SCC-SC-CS (5.6 MPa), showing that the bonding strength in the interfacial transition zone (ITZ) is similar (good quality) for both aggregates. 


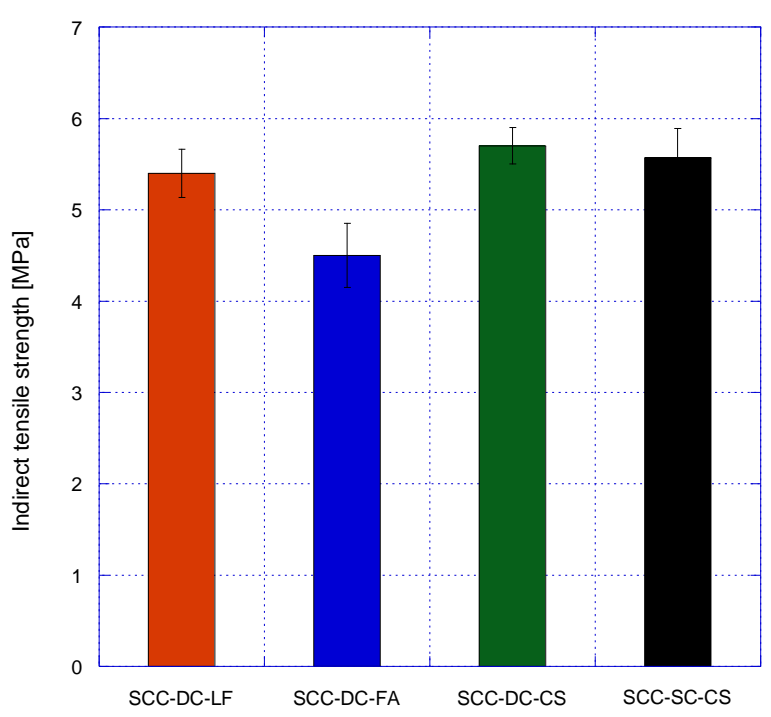

Figure 9. Tensile splitting strength at 90 days for all mixes.

The main mechanical properties of these mixes have been established, however, as future work it is proposed to check the functionality of conventional mechanical models for these materials and the creation of new models if necessary. These models will allow predicting the post-crack behavior of the material and the damage mechanisms for complex structures, using finite-element numerical approaches, as they are widely addressed in the literature [41].

\section{Conclusions}

This research deals with the recycling of two by-products, cupola slag and electric arc furnace slag, to obtain high-performance self-compacting concrete and the comparison of these with similar concrete mixes using high-quality natural aggregates (diabase) and the most common SCMs. After analyzing the rheological and physical-mechanical results obtained, the following conclusions can be drawn:

- It is possible to obtain a viscous paste that is capable of maintaining high-density EAFS particles in suspension by incorporating fillers. A very homogeneous, symmetrical, and stable distribution of the mixture has been achieved, without segregation or concentration of coarse aggregates, despite the high density of slags. In turn, EAFS reduces concrete slump and passing ability by $10 \%$, while the flow rates are reduced more noticeably compared to reference mixes, due to their high viscosity.

- The incorporation of EAFS coarse and fine aggregates increases the density by $15 \%$ with respect to the reference mixes, obtaining high density concretes $\left(>2800 \mathrm{~kg} / \mathrm{m}^{3}\right)$. The open porosity of all mixes is very similar (5-6\%) except for the mix that uses fly ash, due to a gasifying reaction with the superplasticizer additive. Likewise, the high content of rapid cement and the low $\mathrm{w} / \mathrm{c}$ ratio have resulted in all mixes thixotropy gelation of the paste, more pronounced effect on concrete with EAFS.

- For the different cement replacements by cupola slag in mortars, it is worth mentioning the low speed of the reactions of the cupola slag, showing compressive and flexural strengths similar to mortars without replacement for ages of 90 days.

- The incorporation of cupola slag leads to an increase in compressive strength after 28 days of about $10 \%$ with respect to other SCM's. The use of EAFS aggregate provides a $5 \%$ improvement in the compressive strength with respect to diabase using the same SCM. The mixes that incorporate cupola slag SCM have evolved twice as much as the rest of the mixes from 28 to 360 days. The elastic modulus of mixes with EAFS is $24 \%$ higher than the mixes with diabase and the elastic 
modulus of mixes that use slag cupola powder is $10 \%$ higher than the mixes with traditional fillers. In the case of the elastic modulus, practically $90 \%$ of the value at 360 days is obtained after 7 days. No significant differences were found in the tensile splitting strength at 90 days for all the mixes.

Author Contributions: Conceptualization, J.A.P. and C.T.; methodology, C.T. and I.S.; validation, J.A.P. and J.S.; formal analysis, I.S. and P.T.; investigation, I.S.; data curation, I.S.; writing-original draft preparation, I.S. and P.T.; writing-review and editing, C.T. and P.T.; visualization, I.S.; supervision, J.A.P. and C.T.; project administration, C.T. and J.A.P. All authors have read and agreed to the published version of the manuscript.

Funding: This research received no external funding.

Acknowledgments: The authors of this research would like to thank GLOBAL STEEL WIRE for the EAF slag supply and Saint Gobain Pam España for the Cupola Furnace Slag as well as ROCACERO for providing the cement, natural aggregates and superplasticizer additive.

Conflicts of Interest: The authors declare no conflict of interest.

\section{References}

1. World Steel Association (Worldtsteel), World Steel in Figures. 2018. Available online: https://www.worldsteel. org/en/dam/jcr:f9359dff-9546-4d6b-bed0-996201185b12/World+Steel+in+Figures+2018.pdf (accessed on 17 December 2019).

2. Fiol, F.; Thomas, C.; Muñoz, C.; Ortega-López, V.; Manso, J.M. The influence of recycled aggregates from precast elements on the mechanical properties of structural self-compacting concrete. Constr. Build. Mater. 2018, 182, 309-323. [CrossRef]

3. Martuscelli, C.C.; Santos, J.C.d.; Oliveira, P.R.; Panzera, T.H.; Aguilar, M.T.P.; Garcia, C.T. Polymer-cementitious composites containing recycled rubber particles. Constr. Build. Mater. 2018, 170, 446-454. [CrossRef]

4. Norambuena-Contreras, J.; Thomas, C.; Borinaga-Treviño, R.; Lombillo, I. Influence of recycled carbon powder waste addition on the physical and mechanical properties of cement pastes. Mater. Struct. Constr. 2016, 49, 5147-5159. [CrossRef]

5. Rojas, M.F.; de Rojas, M.I.S. Chemical assessment of the electric arc furnace slag as construction material: Expansive compounds. Cem. Concr. Res. 2004, 34, 1881-1888. [CrossRef]

6. Muhmood, L.; Vitta, S.; Venkateswaran, D. Cementitious and pozzolanic behavior of electric arc furnace steel slags. Cem. Concr. Res. 2009, 39, 102-109. [CrossRef]

7. Manso, J.M.; Gonzalez, J.J.; Polanco, J.A. Electric arc furnace slag in concrete. J. Mater. Civ. Eng. 2004, 16, 639-645. [CrossRef]

8. Manso, J.M. Manufacture of Hydraulic Concrete with Electric Arc Furnace Slags. 2001. Available online: https://dialnet.unirioja.es/servlet/tesis?codigo=246266 (accessed on 17 December 2019).

9. Sainz-Aja, J.; Carrascal, I.; Polanco, J.A.; Thomas, C.; Sosa, I.; Casado, J.; Diego, S. Self-compacting recycled aggregate concrete using out-of-service railway superstructure wastes. J. Clean. Prod. 2019, 230, 945-955. [CrossRef]

10. Sainz-Aja, J.; Carrascal, I.; Polanco, J.A.; Thomas, C. Fatigue failure micromechanisms in recycled aggregate mortar by $\mu \mathrm{CT}$ analysis. J. Build. Eng. 2020, 28, 101027. [CrossRef]

11. Thomas, C.; Setién, J.; Polanco, J.A.; de Brito, J.; Fiol, F. Micro- and macro-porosity of dry- and saturated-state recycled aggregate concrete. J. Clean. Prod. 2019, 211, 932-940. [CrossRef]

12. Thomas, C.; Setién, J.; Polanco, J.A.; Cimentada, A.I.; Medina, C. Influence of curing conditions on recycled aggregate concrete. Constr. Build. Mater. 2018, 172, 618-625. [CrossRef]

13. Thomas, C.; Setién, J.; Polanco, J.A.; Alaejos, P.; de Juan, M.S. Durability of recycled aggregate concrete. Constr. Build. Mater. 2013, 40, 1054-1065. [CrossRef]

14. Uysal, M.; Yilmaz, K. Effect of mineral admixtures on properties of self-compacting concrete. Cem. Concr. Compos. 2011, 33, 771-776. [CrossRef]

15. Puertas, F.; Santos, H.; Palacios, M.; Martínez-Ramírez, S. Polycarboxylate superplasticiser admixtures: Effect on hydration, microstructure and rheological behaviour in cement pastes. Adv. Cem. Res. 2005, 17, 77-89. [CrossRef] 
16. Ye, G.; Liu, X.; de Schutter, G.; Poppe, A.-M.; Taerwe, L. Influence of limestone powder used as filler in SCC on hydration and microstructure of cement pastes. Cem. Concr. Compos. 2007, 29, 94-102. [CrossRef]

17. Ramezanianpour, A.A.; Ghiasvand, E.; Nickseresht, I.; Mahdikhani, M.; Moodi, F. Influence of various amounts of limestone powder on performance of Portland limestone cement concretes. Cem. Concr. Compos. 2009, 31, 715-720. [CrossRef]

18. Domone, P.L. Self-compacting concrete: An analysis of 11 years of case studies. Cem. Concr. Compos. 2006, 28, 197-208. [CrossRef]

19. Khayat, K.; de Schutter, G. Mechanical Properties of Self-Compacting Concrete; State of the Art Report RILEM TC 228-MPS; Springer: Berlin/Heidelberg, Germany, 2014.

20. Rozière, E.; Granger, S.; Turcry, P.; Loukili, A. Influence of paste volume on shrinkage cracking and fracture properties of self-compacting concrete. Cem. Concr. Compos. 2007, 29, 626-636. [CrossRef]

21. Loser, R.; Leemann, A. Shrinkage and restrained shrinkage cracking of self-compacting concrete compared to conventionally vibrated concrete. Mater. Struct. 2009, 42, 71-82. [CrossRef]

22. Arum, C.; Mark, G.O. Partial Replacement of Portland Cement by Granulated Cupola Slag-Sustainable Option for Concrete of Low Permeability. Civ. Environ. Res. 2014, 6, 17-26.

23. Domone, P.L. A review of the hardened mechanical properties of self-compacting concrete. Cem. Concr. Compos. 2006, 29, 1-12. [CrossRef]

24. EFNARC. Specification and Guidelines for Self-Compacting Concrete; European Federation for Specialist Construction Chemicals and Concrete Systems: Norfolk, UK, 2005.

25. Holschemacher, K. Hardened material properties of self-compacting concrete. J. Civ. Eng. Manag. 2004, 10, 261-266. [CrossRef]

26. Papayianni, I.; Anastasiou, E. Production of high-strength concrete using high volume of industrial by-products. Constr. Build. Mater. 2010, 24, 1412-1417. [CrossRef]

27. Arribas, I.; Santamaría, A.; Ruiz, E.; Ortega-López, V.; Manso, J.M. Electric arc furnace slag and its use in hydraulic concrete. Constr. Build. Mater. 2015, 90, 68-79. [CrossRef]

28. Sedran, T.; de Larrard, F.; Hourst, F.; Contamines, C. Mix Design of Self-Compacting Concrete. In Proceedings of the RILEM International Conference on Production Methods and Workability of Concrete, Glasgow, Scotland, 3-5 June 1996; pp. 439-450.

29. Pellegrino, C.; Cavagnis, P.; Faleschini, F.; Brunelli, K. Properties of concretes with Black/Oxidizing Electric Arc Furnace slag aggregate. Cem. Concr. Compos. 2013, 37, 232-240. [CrossRef]

30. Manso, J.M.; Polanco, J.A.; Losanez, M.; Gonzalez, J.J. Durability of concrete made with EAF slag as aggregate. Cem. Concr. Compos. 2006, 28, 528-534. [CrossRef]

31. Sheen, Y.-N.; Le, D.-H.; Sun, T.-H. Innovative usages of stainless steel slags in developing self-compacting concrete. Constr. Build. Mater. 2015, 101, 268-276. [CrossRef]

32. Santamaría, A.; Orbe, A.; Losañez, M.M.; Skaf, M.; Ortega-Lopez, V.; González, J.J. Self-compacting concrete incorporating electric arc-furnace steelmaking slag as aggregate. Mater. Des. 2017, 115, 179-193. [CrossRef]

33. Santamaría, A.; Ortega-López, V.; Skaf, M.; Chica, J.A.; Manso, J.M. The study of properties and behavior of self compacting concrete containing Electric Arc Furnace Slag (EAFS) as aggregate. Ain Shams Eng. J. 2019. [CrossRef]

34. Qasrawi, H. Towards sustainable self-compacting concrete: Effect of recycled slag coarse aggregate on the fresh properties of SCC. Adv. Civ. Eng. 2018, 2018, 1-9. [CrossRef]

35. Dinakar, P.; Sethy, K.P.; Sahoo, U.C. Design of self-compacting concrete with ground granulated blast furnace slag. Mater. Des. 2013, 43, 161-169. [CrossRef]

36. Ministerio de Fomento de España (Spain), Spanish Structural Concrete Standard (EHE-08)—In Spanish. 2008. Available online: https://www.fomento.gob.es/organos-colegiados/mas-organos-colegiados/comisionpermanente-del-hormigon/cph/instrucciones/ehe-08-version-en-castellano (accessed on 17 December 2019).

37. BIMB; CEMBUREAU; ERMCO; EFCA; EFNARC. The European Guidelines for Self-Compacting Concrete. Specification, Production and Use. 2005. Available online: https://www.theconcreteinitiative.eu/images/ ECP_Documents/EuropeanGuidelinesSelfCompactingConcrete.pdf (accessed on 17 December 2019).

38. Stroup, W.W.; Stroup, R.D.; Fallin, J.H. Cupola Slag Cement Mixture and Methods of Making and Using the Same. U.S. Patent 6,521,039, 18 February 2003.

39. Kang, S.-H.; Hong, S.-G.; Moon, J. The use of rice husk ash as reactive filler in ultra-high performance concrete. Cem. Concr. Res. 2019, 115, 389-400. [CrossRef] 
40. Stochino, F.; Pani, L.; Francesconi, L.; Mistretta, F. Cracking of Reinforced Recycled Concrete Slabs. Int. J. Struct. Glass Adv. Mater. Res. 2017, 1, 3-9. [CrossRef]

41. Amadio, C.; Bedon, C.; Fasan, M.; Pecce, M.R. Refined numerical modelling for the structural assessment of steel-concrete composite beam-to-column joints under seismic loads. Eng. Struct. 2017, 138, $394-409$. [CrossRef] 